\author{
JÓZEF POROSA \\ Uniwersytet Mikołaja Kopernika w Toruniu \\ jozef.porosa98@gmail.com
}

ORCID: 0000-0002-2129-9916

\title{
Umowa o pracę na czas określony po nowelizacji w 2016 r.
}

\author{
Fixed-term employment contract after the 2016 amendment
}

\begin{abstract}
Streszczenie. Fundament umowy o pracę na czas określony sięga okresu, zanim sama gałąź prawa pracy wyodrębniła się spod reżimu regulacji cywilnej i administracyjnej. Z biegiem lat, kształt tej podstawy nawiązania stosunku pracy zmieniał się pod wpływem różnych czynników, w szczególności wytycznych kreowanych na obszarze pozakrajowym. W związku z tym najbardziej intensywny rozwój obserwuje się w tzw. okresie unijnym, trwającym nieprzerwanie od lat 90 . XX w. Ostatnią zmianą w przedmiocie rozważań, stanowiąca swoistą konkluzję dotychczasowego spojrzenia na umowę o pracę na czas określony, jest nowelizacja wprowadzona ustawą z dnia 25 czerwca 2015 r. o zmianie ustawy - Kodeks pracy i niektórych innych ustaw (Dz.U. z 2015 r. poz. 1220). To właśnie w jej perspektywie, nie porzucając jednak całokształtu dorobku legislacyjnego i doktrynalnego, autor pragnie poruszyć takie zagadnienia jak klarowność pojmowania tej instytucji, ekspansja umowy bezterminowej na kształt umowy o pracę na czas określony, zasada limitacji i długość umów w przypadku stosowania wyjątków od powyższej zasady. Ponadto celem niniejszego opracowania jest dwutorowa ocena stabilności zatrudnienia na podstawie umowy o pracę na czas określony.
\end{abstract}

Słowa kluczowe: umowa o pracę na czas określony; kryterium kwalifikacji; zasada limitacji; dychotomia przesłanek; tryb związkowy; zasadność wypowiedzenia.

Summary. The basis of the fixed-term employment contract goes back to the times when labor law extracted itself from the regime of civil and administrative regulations. Over the years, the shape of this basic form of establishing employment relationship has changed because of different factors, particularly because of guidelines created beyond the borders of Poland. Therefore, the most intense development is observed during so-called EU period that have lasted since 1990s without any interruptions. The last change in the subject matter that constitutes for a conclusion of the existing view on the fixed-term employment contract is the amendment that was implemented with the act of 25th June 2015 on changing the Labor Code and certain other acts (Dz. U z 2015 r. poz. 1220). The author is going to address such concepts as the clarity of understanding this institution; open-end contract's expansion similar to the form of the fixed-term employment contract; the limitation rule; and the duration of contracts when it comes to exceptions to this rule. Furthermore, the aim of this report is an assessment of the stability of employment that is based on the fixed-term employment contract. 
Keywords: fixed-term employment contract; eligibility criterion; limitation principle; dichotomy of premises; union mode; legitimacy of termination.

Data przesłania artykułu do Redakcji: 22.03.2020 r.

Data akceptacji artykułu przez Redakcję: 12.07.2020 r.

\section{Uwagi definiujące umowę o pracę na czas określony}

Umowa o pracę to wyróżniona kodeksowo czynność prawna, na podstawie której strony nawiązują ze sobą więź prawną, zwaną stosunkiem pracy. Dokonując analizy przepisów Kodeksu pracy, należy zauważyć, że ustawodawca, posługując się kryterium temporalności i prakseologiczności ${ }^{1}$, dokonał podziału tej podstawy. Wyróżnił umowę na czas nieokreślony, na czas określony i na okres próbny. Wtórując zasadzie swobody nawiązywania stosunku pracy (art. 11 k.p.) $)^{2}$, wybór konkretnego rodzaju zależy przede wszystkim do samych zainteresowanych. Ograniczeniem dla stron w tym zakresie są jedynie przepisy ramowe, dotyczące reglamentowania możliwości zawierania umów na czas określony i na okres próbny. Przepisy te chronią pracowników, których pozycja przy nawiązywaniu stosunków pracy, mimo autonomii w dokonywaniu czynności prawnych, sprowadzającej się do swobody wyboru partnera i kształtowania treści czynności prawnych, jest $\mathrm{z}$ racji charakteru tego podmiotu wyraźnie niższa niż pracodawcy. Również sam kierunek, w którym prawo pracy powinno podążać, mianowicie rozpowszechnianie umów o pracę na czas nieokreślony ${ }^{3}$, jest ustabilizowany dzięki tym regulacjom. Jednak nie można w związku z powyższym marginalizować znaczenia pozostałych rodzajów, w szczególności umowy o pracę na czas określony.

Definicję tej konsensualnej czynności prawnej, obok zaakcentowania terminu końcowego, najlepiej oddać wskazując cel, który ma realizować. Potoczne ujęcie, zamykające się w rozumieniu tej czynności jako „ograniczone w czasie porozumienie dwóch osób (...), na podstawie którego jedna z nich, tj. pracownik, ma odpłatnie wykonywać jakąś pracę na rzecz drugiej, tj. pracodawcy”, jest niewystarczające. Porzucając precyzję w tym aspekcie,

\footnotetext{
${ }^{1} \mathrm{~K}$. Łapiński, Umowa o pracę na czas określony w polskim i unijnym prawie pracy, Warszawa 2011, s. 62.

${ }^{2}$ Ustawa z dnia 26 czerwca 1974 r. Kodeks pracy (tekst jedn.: Dz.U. 2019 poz. 1040, ze zm.), dalej jako: k.p.

${ }^{3}$ M. Święcicki, Prawo pracy, Warszawa 1968, s. 182.

${ }^{4}$ K. Lapiński, Umowa..., s.63.
} 
powodowalibyśmy na gruncie języka prawniczego wieloznaczność tego terminu, co byłoby zjawiskiem niepożądanym. Zatem chcąc odróżnić ją od obecnie występującej w prawie pracy innej, również terminowej umowy, należy rozwinąć dwa zagadnienia.

Pierwszym jest termin końcowy, który powoduje „istnienie więzi prawnej między stronami tylko przez ściśle oznaczony przez nie, już w momencie zawierania, okres"5. Ścisłości tej nie można jednak zawsze oceniać w granicach definitywności. Istnieją bowiem dwie metody wykorzystywane do oznaczenia terminu końcowego. Pierwsza, pozostająca w tych granicach, to metoda bezpośrednia. Polega na wyznaczeniu w treści umowy konkretnej, kalendarzowej daty albo okresu, po upłynięciu których stosunek pracy ulega rozwiązaniu. Druga, zwana pośrednią, skutek w postaci ustania stosunku pracy łączy z nastąpieniem określonego zdarzenia ${ }^{6}$. Zdarzenie to powinno być przyszłe, pewne ${ }^{7} \mathrm{i}$,ppoparte okolicznościami uzasadniającymi wprowadzenie do umowy tego zdarzenia jako powodującego wygaśnięcie stosunku umownego" ${ }^{\text {. }}$. Widać zatem, że ścisłość oznaczenia okresu nie jest definitywna, a na pewno nie zawsze. W różnych okolicznościach, mowa tutaj głównie o metodzie pośredniej, moment rozwiązania umowy o pracę na czas określony może nastąpić na przestrzeni kilku czy kilkunastu dni. Okres wyczekiwania w takich sytuacjach uzależniony jest głównie od specyfiki przyjętego zdarzenia. Po nowelizacji Kodeksu pracy w 2016 r. i ograniczeniu form umów terminowych takie pojmowanie terminu końcowego wydaje się tym bardziej prawidłowe, ponieważ aktualnie należy szerzej odbierać umowę o pracę na czas określony. Nie można bezrefleksyjnie stosować terminów ścisłych bezwzględnie w przypadkach zatrudnienia na czas zastępstwa czy wykonania określonej pracy, jedynie z uwagi na nazwę umowy. „Prowadziłoby to do niespójności systemowej,

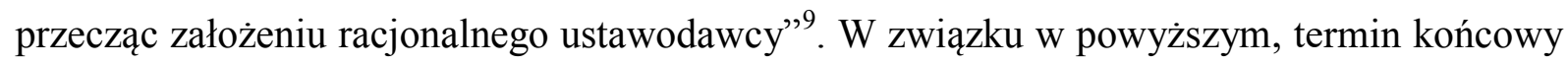
powinien być określany ad casum, opierając się na okolicznościach danego zatrudnienia ${ }^{10}$.

Drugim zagadnieniem definiującym umowę o pracę na czas określony jest wcześniej wspomniana causa. W doktrynie przyjęto, że „zawierana jest w celu wykonywania zadań

\footnotetext{
${ }^{5}$ E. Wichrowska-Janikowska, Umowa o pracę na czas określony i na zastępstwo - jej wplyw na kształtowanie rynku pracy - na podstawie działań Rzecznika Praw Obywatelskich, w: Konferencja naukowa „Umowa o prace na czas określony - jej rola $i$ znaczenie $w$ kreowaniu stosunków pracy”, red. E. Wichrowska-Janikowska, Warszawa 2004, s. 8.

${ }^{6}$ K. Łapiński, Umowa ..., s. 66-67.

${ }^{7}$ Tamże, s. 66.

${ }^{8}$ Orzeczenie SN z dnia 15 grudnia 1956 r., IV CR 35/56, OSNCK 1957, nr 4, poz.118.

${ }^{9}$ Ł. Pisarczyk, Nowy model zatrudnienia pracowniczego w prawie pracy? - czesść 1, Monitor Prawa Pracy 2016, nr 4, s. 177.

10 Tamże, s. 177.
} 
oznaczonych w czasie, może zatem być stosowana ze względu na okresowy charakter pracy pewnych grup zawodowych bądź dla zapewniania obsady stanowisk pracowniczych w pewnych okresach wzmożonego zapotrzebowania na pracę" ${ }^{\prime 1}$. Warto dodać, że umowa o pracę na czas określony może służyć pracodawcy jako instrument pozwalający czasowo uzupełnić braki personalne. Niekiedy również sam pracownik zainteresowany jest nawiązaniem stosunku pracy na ściśle określony czas. Tak przedstawia się stanowisko doktryny, wykształcone z uwagi na brak konkretnej regulacji w tym zakresie. Nie należy jednak poprzestać na tym stanowisku, gdyż wydaje się ono niepełne.

Biorąc pod uwagę, że tworzenie definicji ma przede wszystkim pełnić funkcję odróżniającą, warto pochylić się nad celem umowy o prace na okres próbny, gdyż po 2016 r. to właśnie ten rodzaj umowy o pracę, obok umowy na czas określony, zamyka katalog umów terminowych. Analizując cel umowy na okres próbny, określony w art. 25 §2k.p., mianowicie „sprawdzenie kwalifikacji pracownika i możliwości jego zatrudnienia w celu wykonywania określonego rodzaju pracy”, należy zauważyć gradację przesłanki, która pozwoli rozgraniczyć i co za tym idzie ułatwić stosowanie umowy o pracę na czas określony i na okres próbny. Przesłanką, o której mowa, są kwalifikacje pracownika. Jednak nie należy rozumieć ich w perspektywie posiadania, gdyż mając na względzie przepis $z$ art. $237^{3} \S 1$ k.p., zgodnie z którym „nie wolno dopuścić pracownika do pracy, do której wykonywania nie posiada on wymaganych kwalifikacji lub potrzebnych umiejętności”, zastosowalibyśmy interpretację contra legem. W związku z powyższym poprawnym byłoby przyjęcie kryterium przełożenia kwalifikacji na praktykę. W takim ujęciu problemu umowa na okres próbny ma zastosowanie wtedy, gdy np. pracodawca, świadomy faktu, że niektórzy kandydaci na pracowników posiadają kwalifikacje pozorne, niepoparte w umiejętnościach, nie chcąc powodować wzrostu ryzyka osobowego, nawiązuje stosunek pracy celem ich sprawdzenia. Z kolei umowa na czas określony powinna mieć zastosowanie w sytuacjach, gdy pracodawca nawiązuje stosunek pracy z pracownikiem, co do którego nie ma wątpliwości, że kwalifikacje, którymi się legitymuje, mają odzwierciedlenie w rzeczywistości, jednak z przyczyn wymienionych wyżej nie nawiązuje stosunku pracy na podstawie umowy o pracę na czas nieokreślony. Opisany warunek spełnia się, jeśli rozważamy zagadnienie ze strony pracodawcy. Pamiętać należy, że celem umowy na okres próbny, nieokreślonym explicite przez ustawodawcę, jest także nabycie przez pracownika wiedzy dotyczącej warunków panujących w zakładzie pracy, na podstawie której może podjąć decyzję o dalszej współpracy z pracodawcą. Perspektywy tej

\footnotetext{
${ }^{11}$ L. Florek, Prawo pracy, Warszawa 2006, s. 72.
} 
nie można pominąć, ponieważ implikujemy z niej kolejną różnicę pomiędzy dwiema umowami terminowymi.

\section{Normatywne aspekty umowy o pracę na czas określony}

Kształtowanie się regulacji dotyczących umowy o pracę na czas określony w Polsce można podzielić na cztery okresy. Pierwszym jest dwudziestolecie międzywojenne, następnie okres powojenny do 1976 r., od 1976 r. do 1996 r. i ostatni, trwający do dnia dzisiejszego okres unijny $^{12}$, który opiera się na dyrektywach, w szczególności Dyrektywie Rady 99/70/WE z dnia 28 czerwca 1999 r. Wiodącą regulacją ostatniego okresu jest nowelizacja Kodeksu pracy z 2016 r. Dokonano w niej ograniczonej unifikacji umów terminowych, zmieniono przepisy dotyczące rozwiązywania umów o pracę na czas określony, implementowano także kolejną wersję zasady limitacji tych umów. Ostatnia z wymienionych zmian wymagała rewizji spojrzenia na treść tej czynności prawnej, czego skutek również znalazł odzwierciedlenie w Kodeksie pracy po 2016 r.

Ograniczona unifikacja wiąże się ze zmniejszeniem ilości form umów terminowych, uwzględnionych przez ustawodawcę w art. 25 k.p. Przed 2016 r. oprócz umów zawieranych na okres próbny i czas określony, które widnieją obecnie w tym przepisie, ustawodawca wyróżnił jeszcze umowę na czas wykonywania określonej pracy. Brak takiej formy w obecnym stanie prawnym dla niektórych jest „sygnałem, że prace, które dotychczas były świadczone $\mathrm{w}$ ramach jednej $\mathrm{z}$ terminowych umów o pracę, można będzie wykonywać na podstawie cywilnoprawnej umowy o dzieło"13. Teza ta skłaniałaby jednak do rozumienia takiego działania jako narzucenia przez ustawodawcę kierunku sprzecznego z przyjętym dotychczas, mianowicie promowania prawa pracy jako środka ochrony zatrudnionych. Z punktu widzenia funkcji ochronnej nie można dopuścić do ograniczenia zakresu stosowania modelu pracowniczego na rzecz cywilnoprawnego modelu zatrudnienia. Dlatego właśnie włączenie umowy o pracę na czas wykonywania określonej pracy pod egidę umowy o pracę na czas określony wydaje się najlepiej spełniać założenie racjonalnego ustawodawcy. Unifikacja ta jest jednak tylko ograniczona, ponieważ katalog umów terminowych zawiera także umowę o pracę na okres próbny. Nie wydaje się jednak, zważywszy na realizowane przez nią cele, by w przyszłości dopuszczono do jej zniesienia.

\footnotetext{
${ }^{12}$ K. Lapiński, Umowa ..., s. 34-47.

${ }^{13}$ A. Świątkowski, Kodeks pracy. Komentarz, Warszawa 2018, Legalis.
} 
Naturalną konsekwencją nowelizacji art. 25 k.p. była także zmiana katal rozwiązania umów o pracę. Ukończenie pracy, będące zdarzeniem stricte przez umowy o pracę na czas wykonywania określonej pracy, zostało uchylone z przedmiotu, któremu mogłoby służyć. W związku z tym po 21 lutego 2016 o pracę na czas określony zastosowanie może mieć każdy sposób określony Wśród tych sposobów, z perspektywy umowy o pracę na czas określony, uwagę zasługują zmiany dotyczące rozwiązania umowy o pracę za wyp Dotychczas, przy tego rodzaju umowie, nie istniała możliwość złożenia oświa ze stron o rozwiązaniu umowy z zachowaniem okresu wypowiedzenia na pods Kodeksu pracy. Drogę do takiego działania zamknięto poprzez enumeratyw w art. 32 k.p. rodzajów umów, przy których zainteresowana strona była do teg Równocześnie ustawodawca wprowadził możliwość regulowania tego zaga same strony. Uchylony art. 33 k.p. upoważniał do rozwiązania umowy na czas wypowiedzeniem, ale tylko na podstawie woli stron uwzględnionej przy zawie Dodatkowo możliwość taką posiadali jedynie partnerzy, których umowa obowi dłużej niż 6 miesięcy, przy czym ustalony okres wypowiedzenia, biorąc pod uprzywilejowania pracownika, nie mógł być krótszy niż 2 tygodnie ${ }^{14}$.

Regulacja sprzed 2016 r. kształtowała ten rodzaj umowy o pra symptomatyczny sposób. Inaczej sytuacja wygląda obecnie. Wraz z nowelizacją w życie 22 lutego 2016 r., dokonano generalizacji przepisów i co za tym idzie tożsamości umowy o pracę na czas określony ${ }^{15}$. Ustawodawca poddał bowiem dotyczącego wypowiadania umów o pracę na czas nieokreślony także um określony $^{16}$. Nie jest zatem konieczne wcześniejsze wprowadzenie takiej drodze konsensualnej. W takiej procedurze można regulować, w granicac korzystniejszych dla pracownika, niż to określone w Kodeksie pracy, dł wypowiedzenia $^{17}$. Pamiętać przy tym należy, że rozstrzygnięcie w przedmi postanowienia o dłuższym okresie wypowiedzenia podejmowane jest w persp faktycznego, istniejącego w momencie zawierania umowy. W szczególnoś 
uwagę na treść czynności prawnej i jej emanację w życiu pracownika ${ }^{18}$. W przypadku niewykorzystania możliwość uregulowania przez strony w sposób odmienny materii związanej z okresami wypowiedzenia albo uregulowania jej niezgodnie $\mathrm{z}$ obowiązującymi standardami, zastosowanie mają przepisy Kodeksu pracy. Ustawodawca ich długość determinuje czasem zatrudnienia u danego pracodawcy. Wyjątkiem jest sytuacja, w której zakład pracy lub jego część przechodzi na innego pracodawcę, a także wtedy, gdy odrębne przepisy określają nowego pracodawcę następcą prawnym poprzednika. W związku $\mathrm{z}$ powyższym, okres wypowiedzenia $\mathrm{w}$ takich warunkach wynosi 2 tygodnie, jeśli zatrudnienie nie przekraczało 6 miesięcy, 1 miesiąc, gdy wynosiło więcej niż 6 miesięcy, ale mniej niż 3 lata oraz 3 miesiące, przy zatrudnieniu pracownika przez 3 lata i więcej. Ostatni termin w szczególnym momencie dla pracodawcy może ulec skróceniu, nie więcej jednak niż do 1 miesiąca. Sytuacja taka aktualizuje się w przypadku wypowiedzenia umowy o pracę zawartej na czas określony lub nieokreślony z przyczyn niedotyczących pracowników. Przede wszystkim będzie to ogłoszenie upadłości lub likwidacji, ale także, na co wskazuje art. 1 ustawy $\mathrm{z}$ dnia 13 marca 2003 r. o szczególnych zasadach rozwiązywania z pracownikami stosunków pracy $\mathrm{z}$ przyczyn niedotyczących pracowników (tekst jedn.: Dz.U. 2018 poz. 1969, ze zm.), zmiany organizacyjne, produkcyjne lub technologiczne, jak również wówczas, gdy zmiany mają na celu poprawę warunków pracy lub środowiska naturalnego. Indyferentnym jest w takich okolicznościach, ilu pracowników zatrudnia pracodawca ${ }^{19}$. Dla ważności tego jednostronnego działania, zdaniem Sądu Najwyższego, potrzeba natomiast świadomości pracownika co do skutków wypowiedzenia, już w momencie złożenia oświadczenia woli ${ }^{20}$. Skracając okres wypowiedzenia, pracodawca powinien mieć na względzie obowiązek wypłacenia pracownikowi odszkodowania z tego tytułu. Odszkodowanie jest substytutem wynagrodzenia, w związku z czym obowiązek wypłaty skorelowany jest wyłącznie $\mathrm{z}$ przysługującym pracownikowi prawem do wynagrodzenia za skrócone okresy ${ }^{21}$.

\section{Problem odnawialności umowy o pracę na czas określony}

Jak już zostało przytoczone, bieżący okres rozwoju umowy o pracę na czas określony, nazwany na potrzeby pracy okresem unijnym, kształtowany jest z myślą o dostosowaniu

\footnotetext{
${ }^{18}$ W. Muszalski, Komentarz do art. 36 Kodeksu pracy, w: Kodeks pracy. Komentarz, red. W. Muszalski, Warszawa 2019, Legalis.

${ }^{19}$ L. Mitrus, Komentarz do art. $36^{1}$ Kodeksu pracy, w: Kodeks pracy. Komentarz, red. A. Sobczyk, Warszawa 2018, Legalis.

${ }^{20}$ Wyrok SN z dnia 8 maja 1997 r., I PKN 123/97, OSNAPiUS 1998, nr 5, poz. 151.

${ }^{21}$ A. Świątkowski, Kodeks pracy. Komentarz, Warszawa 2018, Legalis.
} 
polskiej regulacji do standardów europejskich. Dyrektywy, które oddziałują na problem odnawialności umów o pracę na czas określony, były impulsem do pojawienia się zasady limitacji $^{22}$ i towarzyszą jej przez cały okres obowiązywania. Po raz pierwszy, stymulowana Dyrektywą Rady 91/383/EWG z dnia 25 czerwca 1991 r., zasada ta pojawiła się w polskim ustawodawstwie wraz z nowelizacją Kodeksu pracy z dnia 2 lutego 1996 r. W myśl wprowadzonego tym aktem prawnym art. $25^{1} \mathrm{k}$.p. strony miały prawo zawrzeć dwie umowy o pracę na czas określony, a kolejna tego typu umowa, zawarta pomiędzy tymi podmiotami w ciągu miesiąca od rozwiązania poprzedniej i nawiązania następnej, przekształcała się w umowę na czas nieokreślony. Przepis ten w niezmienionym brzmieniu obowiązywał do 2002 r., kiedy jego stosowanie zostało zawieszone do czasu przystąpienia Rzeczypospolitej do Unii Europejskiej. Kolejne zmiany opierały się na Dyrektywie Rady 99/70/WE z dnia 28 czerwca 1999 r. Zaproponowano w niej trzy sposoby regulacji tej materii, mianowicie ustalenie dopuszczalnej ilości umów o pracę na czas określony, wskazanie zobiektywizowanych przesłanek umożliwiających odnowienie, a także maksymalną długość ich obowiązywania. Inspirowany tymi wytycznymi ustawodawca, wraz z dniem uzyskania przez Polskę członkostwa Unii, zmienił brzmienie art. $25^{1}$ k.p., akcentując pierwszą i w ograniczonym stopniu drugą metodę regulacji. W ramach pierwszej powtórzył treść przepisu z 1996 r., a wtórując drugiej wskazał sytuacje, które upoważniają strony do zawarcia kolejnej umowy o pracę na czas określony. Zatem mogły być to umowy na czas zastępstwa pracownika $\mathrm{w}$ razie jego usprawiedliwionej nieobecności w pracy, a także gdy prace mające być wykonywane na jej podstawie miały charakter cykliczny, dorywczy lub sezonowy. Nowelizacja dodatkowo rozwiązała problem z tzw. aneksowaniem umów, dotyczącego dołączania do umów aneksów stwierdzających przesunięcie w czasie terminu rozwiązania stosunku pracy ${ }^{23}$. Dokonano tego poprzez uznanie załącznika o tej treści za nawiązanie kolejnej umowy o pracę. To brzmienie zasady limitacji umów na czas określony utrzymało się do 2016 r. Wyjątkiem był okres od 22 sierpnia 2009 r. do 31 grudnia 2011 r. Wtedy to mocą ustawy z dnia 1 lipca 2009 r. o łagodzeniu skutków kryzysu ekonomicznego dla pracowników i przedsiębiorców (Dz.U. 2009 r. Nr 125 poz. 1035, ze zm.), wprowadzono regulację przejściową, która podmiotowo ograniczyła stosowanie art. $25^{1}$ k.p. Ograniczyła, bowiem przepis limitujący zamieszczony w tej ustawie dotyczył umów o pracę na czas określony zawieranych pomiędzy pracownikiem a pracodawcą - przedsiębiorcą. W związku z tym Kodeks pracy w dalszym ciągu pozostawał w mocy obowiązującej np. dla

\footnotetext{
${ }^{22}$ K. Lapiński, Umowa..., Warszawa 2011, s. 47.

23 Tamże, s. 49.
} 
pracowników służby cywilnej czy pracowników samorządowych. Ustawa „antykryzysowa”, jak nazywa się ją w doktrynie, była ważna z punktu widzenia późniejszej regulacji, ponieważ odnosiła się także do trzeciego $\mathrm{z}$ wymienionych sposobów przedstawionych w Dyrektywie Rady 99/70/WE, który został użyty przy zmianach obowiązujących po 2016 r. W myśl art. 13 ustawy ,,antykryzysowej”, pełniącego funkcję analogiczną do art. $25^{1}$ k.p., okres zatrudnienia na podstawie umowy o pracę na czas określony nie mógł być dłuższy niż 24 miesiące - niezależnie od tego, czy stosunek pracy trwał na podstawie jednej czy wielu umów, z tym jednak, że kolejne umowy na czas określony mogły być zawierane po 3 miesiącach od rozwiązania umowy o pracę lub wygaśnięcia stosunku pracy. Umowy o pracę na czas określony, niespełniające tych przesłanek, należało traktować jako umowy o pracę na czas nieokreślony.

Śledząc historię zmian legislacyjnych, nie można nie zauważyć decydującego wpływu dyrektyw na kształt zasady limitacji umów na czas określony. Obecny stan prawny jest syntezą doświadczeń opartych na latach wdrażania środków proponowanych przez Radę. Urzeczywistniane są w teraźniejszym brzmieniu art. $25^{1}$ k.p. wszystkie sposoby regulowania tej materii, ponieważ przepis odnosi się m.in. do maksymalnej długości trwania umowy na czas określony, ilości odnowień i obiektywnych przesłanek, które uzasadniałyby ich zawieranie. Od 22 lutego 2016 r. pracodawca nawiązuje stosunek pracy z pracownikiem na podstawie takich umów terminowych najwyżej na okres 33 miesięcy, a łączna ich liczba nie może przekroczyć trzech. Zawarcie czwartej umowy o pracę na czas określony lub przekroczenie wskazanego okresu jest niedopuszczalne ${ }^{24}$, ale nie powoduje nieważności czynności prawnej, ponieważ w §3 ustawodawca stanowi, że ,pracownik, odpowiednio od dnia następującego po upływie okresu, o którym mowa w $\S 1$, lub od dnia zawarcia czwartej umowy o pracę na czas określony, jest zatrudniony na podstawie umowy o pracę na czas nieokreślony". Skutki niedochowania tych warunków nie rozciągają się jednak w sytuacji społecznie uzasadnionej, regulowanej w art. 177 k.p., czyli przy przedłużeniu umowy o pracę na czas określony do dnia porodu, gdyby ta została rozwiązana po trzecim miesiącu ciąży. Ponadto $\mathrm{w}$ celu uniknięcia praktyki praeter legem powtórzono treść przepisu, wprowadzonego już w 2004 r., który rozwiązywał problem aneksowania umów.

Ostatni sposób wskazany przez Dyrektywę, czyli katalog obiektywnych przesłanek będący mechanizmem wyłączenia zasady limitowania, w porównaniu do obowiązujących

\footnotetext{
${ }^{24}$ W. Muszalski, Komentarz do art. $25^{1}$ Kodeksu pracy, w: Kodeks pracy. Komentarz, red. W. Muszalski, Warszawa 2019, Legalis.
} 
przed 2016 r. przepisów, został poszerzony o dwa elementy. Oprócz mających już swoją historię umów o pracę zawieranych na czas zastępstwa w razie uzasadnionej nieobecności pracownika i w celu wykonywania pracy o charakterze dorywczym lub sezonowym, znalazły się także takie powody jak wykonywanie pracy przez okres kadencji i obiektywne przesłanki leżące po stronie pracodawcy. Wymienione przyczyny nie mogą stanowić samodzielnej podstawy do uchylenia działania zasady. Ustawodawca zobowiązuje do rozpatrywania każdego kazusu osobno, mając na uwadze zaspokojenie rzeczywistego okresowego zapotrzebowania, które w perspektywie stanu faktycznego jest nieodzowne ${ }^{25}$. Oczywiście tak przedstawia się sytuacja $\mathrm{w}$ powszechnym modelu zatrudnienia pracowniczego. Inne podejście, gdzie nie zawsze stosowanie przepisów k.p. jest prawidłowe, obserwujemy w przypadku pragmatyk, które zdaniem Sądu Najwyższego „w sposób wyczerpujący wskazują okoliczności, w których strony mogą zawrzeć umowę o pracę na czas określony. Dotyczy to w szczególności zatrudnienia nauczycieli" ${ }^{26}$.

Rozbudowa całego art. $25^{1}$ k.p., ale w szczególności części dotyczącej przypadków wyłączenia stosowania zasady ograniczającej odnawialność umów o pracę na czas określony, spowodowała konieczność uzupełnienie regulacji dotyczącej treści tej umowy. Ustawodawca, na strony nawiązujące stosunek pracy $\mathrm{W}$ związku $\mathrm{z}$ katalogiem umieszczonym w art. $25^{1} \S 4$ pkt 1 - 4 k.p., nałożył obowiązek wyraźnego wskazania causy zawarcia umowy ${ }^{27}$. Niektóre głosy doktryny nie traktują tej dyspozycji jednolicie. Wydaje się być prawidłowym stwierdzenie, że z treści musi emanować cel, dla realizacji którego umowa została zawarta. Spór pojawia się jednak głębiej. Dotyczy bowiem dokładności w artykułowaniu tego założenia. Można przyjąć, że w przypadkach określonych w pkt $1-3$ tego przepisu wystarczy wskazać sam cel, bez podawania przyczyn uzasadniających, a dopiero w pkt 4 dookreślić cel poprzez zamieszczenie przyczyn w umowie ${ }^{28}$. Nie wydaje się jednak, że taka minimalizacja jest pożądana. Moim zdaniem, mechanizm wyłączenia stosowania zasady limitacji powinien obwarowany być większą dokładnością, gdyż sama zasada, niezależnie od swojego historycznego brzmienia, „ogranicza mechanizmy patologiczne, a także chroni prawa i interesy pracownika”29. Dlatego właśnie stanowisko

\footnotetext{
${ }^{25}$ J. Stelina, Komentarz do art. $25^{1}$ Kodeksu pracy, w: Kodeks pracy. Komentarz, red. A Sobczyk, Warszawa 2018, Legalis.

${ }^{26}$ Wyrok SN z dnia 21 września 2011 r., II PK 36/11, Legalis nr 461864.

${ }^{27}$ A. Świątkowski, Kodeks pracy. Komentarz, Warszawa 2018, Legalis.

${ }^{28}$ Tamże, Legalis.

${ }^{29}$ J. Piątkowski, Umowa ..., s. 13.
} 
drugie, propagujące wskazanie „celu (...) przez podanie obiektywnych przyczyn”,30, niezależnie, do której przesłanki z katalogu umowa się odnosi ${ }^{31}$, powinno być praktykowane.

\section{Problem okresu trwania umowy o pracę na czas określony}

Stosunki pracy nawiązywane na podstawie umowy o pracę na czas określony mogą odpowiadać reżimowi czasowemu narzuconemu w art. $25^{1} \S 1$ k.p. lub nie podpadać pod wskazaną normę. Pierwsza sytuacja nie budzi wątpliwości. Ustawodawca wyraźnie wskazał maksymalną długość obowiązywania omawianej umowy terminowej pomiędzy tymi samymi podmiotami. Problem pojawia się z umowami, co do których nie stosuje się przepisu limitującego. Należy zauważyć dychotomię $\S 4$ art. $25^{1}$ k.p., w którym usankcjonowane są przyczyny pozwalające zawrzeć takie umowy. Dzielą one bowiem umowy niepodpadające pod normę limitującą, ze względu na kryterium ostrości określenia terminu końcowego, na terminowe - bliżej określone i terminowe - nieokreślone. Podział ten, przyjęty na potrzeby niniejszej pracy, wydaje się być uzasadniony. Do pierwszych umów zaliczają się te zawierane w celu zastępstwa, wykonywania pracy o charakterze dorywczym lub sezonowym i na okres kadencji. Termin końcowy $\mathrm{w}$ tych umowach wskazany jest pośrednio, co prawda tak jak w rodzaju terminowym - nieokreślonym, ale w znacznie bardziej zobiektywizowany sposób. I to właśnie ten niewystarczający poziom wyrazistości wśród przesłanek obiektywnych prowadzi do problemu długości umowy o pracę na czas określony.

Powyższe dotyczy oczywiście wyrażonej w art. $25^{1} \S 4$ pkt 4 k.p kategorii stanów faktycznych, których zaistnienie uzasadniałoby uchylenie się od konwersji umowy o pracę na czas określony zawieranej ponad granice temporalne lub ilościowe. Nie są one jednak kazuistycznie wyliczone, co dawałoby pewność stosowania takiej regulacji, niestety powodując przy tym uchybienie sprawiedliwości społecznej, ponieważ sztywna norma charakteryzuje się stagnacją przy potrzebie nieustannego reagowania na zmieniającą się rzeczywistość. Mimo tej ideowo wybranej metodzie regulacji, problem oscyluje wokół zbyt dużej ekspresyjności poprzez klauzule niedookreślone. Ekspresyjność, o której mowa, wiąże się z wielością kwantyfikatorów, na podstawie których ocenia się prawidłowość działania stron zawierających umowę o pracę na czas określony, niewpisującą się w zasadę limitacji. Zatem są to obiektywne przyczyny, które muszą znajdować się po stronie pracodawcy i bezpośrednio wpływać na jego wolę co do zatrudnienia pracownika. Ponadto przyczyny

\footnotetext{
${ }^{30}$ Zob. art. $29 \S 1^{1}$ k.p.

31 J. Stelina, Komentarz do art. $25^{1}$ Kodeksu pracy, w: Kodeks pracy. Komentarz, red. A Sobczyk, Warszawa 2018, Legalis.
} 
odnoszone zawsze do perspektywy przypadku, którego umowa dotyczy, nie mogą stanowić elementu stałej taktyki pracodawcy, a zawarcie umowy musi być niezbędne dla zaspokojenia okresowego zapotrzebowania rozpatrywanego w świetle wszystkich okoliczności towarzyszących tej czynności ${ }^{32}$. Przesłanki te charakteryzują się znaczą dozą uznania. Na ich podstawie można właściwie $\mathrm{w}$ dowolny sposób przyporządkowywać stany faktyczne do kreowanej normy, pomimo tej ekspresyjności, która jako założenie legislacyjne nie może być, moim zdaniem, oceniana negatywnie. Zwiększenie ilości wytycznych, jakimi musi kierować się pracodawca przy zawieraniu umów terminowych - nieokreślonych ma uzasadnienie w nieustannej próbie pogłębiania stabilności umowy o pracę na czas określony, a co za tym idzie, ochronie pracownika. Jednak wytyczne, zgodnie z tym, co zostało wcześniej przytoczone, nie są w wystarczający sposób zobiektywizowane. Praktyka pokazuje, że pracodawcy korzystają $\mathrm{z}$ dobrodziejstw umowy o pracę na czas określony, pozostając faktycznie w stosunku pracy na podstawie umowy o pracę na czas nieokreślony.

Klauzule niedookreślone dają dużą swobodę nie tylko pracodawcom. Także sądy, pochylające się nad zasadnością działań stron umowy na tej płaszczyźnie, korzystają z tego przywileju. Ich rozstrzygnięcia bardzo często pozostają ze sobą w stosunku daleko idącej dyferencji. Sądy bowiem rozpatrują każdą sprawę indywidualnie, odnosząc przyczyny determinujące pracodawcę, czy same jego działania, przede wszystkim do zasad współżycia społecznego i społeczno-gospodarczego przeznaczenia umowy ${ }^{33}$. W związku z powyższym, umowy długoterminowe, zawierane na okres ośmiu lat, mogą zostać uznane za ważne i wiążące dla stron, jako umowy na czas określony. Inaczej jednak będzie z umowami, które zawarte są np. na okres czterech lat, ale całokształt okoliczności wskazuje, że celem nawiązania stosunku pracy na ich podstawie było obejście prawa lub pozaprawnych standardów postępowania wyrażonych w wyżej przytoczonych klauzulach generalnych.

Niedookreślone sformułowania z art. $25^{1} \S 4$ pkt 4 k.p. są poddawane ocenie przez sądy w perspektywie klauzul generalnych, charakteryzujących się jak powszechnie wiadomo, znaczną elastycznością $\mathrm{w}$ pojmowaniu, mimo oparciu ich istoty na akceptowanych w społeczeństwie postawach. Czy jest to odpowiednia praktyka? A może należy ograniczyć w przyszłości możliwość tej oceny na rzecz podejścia jedynie kazuistycznego? Należałoby podjąć nad tym tematem szerszą polemikę. De lege lata sądy według swego uznania rozstrzygają o prawidłowości pojmowania charakteru danej umowy o pracę na czas

\footnotetext{
${ }^{32}$ A. Świątkowski, Kodeks pracy. Komentarz, Warszawa 2018, Legalis.

${ }^{33}$ J. Piątkowski, Umowa ..., s. 18.
} 
określony, co same zresztą forsują. Przykładznajdujemy w wyroku Sądu Najwyższego z dnia 27 maja 2014 r., w tezie którego akcentuje się, że „taka ocena pozostaje w zakresie swobody sędziowskiej i - co do zasady - uchyla się spod kontroli kasacyjnej"34.

\section{Ocena stabilności zatrudnienia na podstawie umowy o pracę na czas określony po zmianach}

Stan prawny, po przyjętym cenzusie, czyli nowelizacji Kodeksu pracy z 2016 r., w sferze dotyczącej stabilności zmienił się jedynie poprzez wprowadzenie możliwości wypowiadania umowy o prac na czas określony bez uprzedniego przyjęcia tego rozwiązania w treści umowy i poza ograniczeniem temporalnym, o czym zostało już wspomniane. Obowiązująca regulacja zakłada możliwość wypowiedzenia tej umowy z inicjatywy pracodawcy bez obowiązku podania przyczyny czy zachowania trybu związkowego. Twierdzenie to uzasadnia fakt, że ustawodawca nie uwzględnił tego rodzaju umowy przy wytycznych dotyczących wypowiadania umowy o pracę na czas nieokreślony ${ }^{35}$. Inna sytuacja kreuje się jednak, gdy do czynienia mamy $\mathrm{z}$ rozwiązaniem natychmiastowym przez pracodawcę, tam bowiem, stosowanie przepisów dotyczących rozwiązania bez wypowiedzenia $\mathrm{z}$ winy pracownika albo bez winy, pociąga za sobą kolejno z mocy art. $52 \S 3$ k.p. i art. $53 \S 4$ k.p. obowiązek wdrożenia procedury konsultacji ze związkiem ${ }^{36}$, który powiadomiony o przyczynie zamiaru zwolnienia, ma prawo zgłosić umotywowane zastrzeżenia.

Przedstawiona właśnie esencja regulacji w przedmiocie rozważań oscyluje wokół zasadności, trybu związkowego i zaliczenia umowy o pracę na czas określony do katalogu podstaw, które mogą być rozwiązywane za wypowiedzeniem. Uwypuklenie ich ma znaczenie, ponieważ te trzy kryteria oddziałują na rzeczywistość, jak i rozważania doktrynalne, a ocena stabilności zatrudnienia na podstawie umowy o pracę na czas określony, niezależnie od okresu, w jakim jest dokonywana, powinna uwzględniać także tożsamość umowy, tj. jej charakter prawny, względem pozostałych rodzajów tej podstawy nawiązania stosunku pracy. $\mathrm{W}$ związku z tym, proponuję podejść do zagadnienia dwutorowo - z jednej strony, abstrahując od miejsca umowy o pracę na czas określony w katalogu umów o pracę, a z drugiej - analizując jej stabilność w ramach systemu, którego jest częścią.

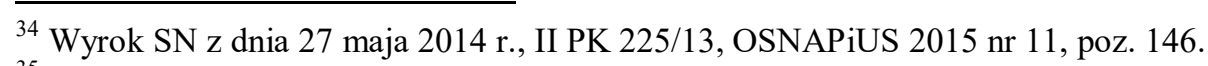

${ }^{35}$ Zob. art. 38 k.p.

${ }^{36}$ J. Piątkowski, Udzial zwiqzku zawodowego w rozwiazywaniu stosunku pracy - niedoskonatości regulacji prawnej, w: Ochrona trwałości stosunku pracy w spolecznej gospodarce rynkowej, red. G. Goździewicz, Warszawa 2010, s. 143.
} 
Pierwsza perspektywa, która dotyczy przede wszystkim odzwierciedlenia w praktyce regulacji kodeksowych, oceniana być powinna negatywnie ${ }^{37}$. Słuszna wydaje się teza, że po granicznej nowelizacji umowa o pracę na czas określony uległa destabilizacji ${ }^{38}$, a na pewno doszło do eskalacji problemu. Od 2016 r. pracownicy pozostający w stosunku pracy na podstawie umowy o pracę na czas określony utracili ochronę bezwzględną, jaką posiadali, o ile umowa ta trwała krócej niż 6 miesięcy. Kolejnym wyznacznikiem tej eskalacji jest ograniczenie ochrony powszechnej stosunku pracy, jedynie do umów o pracę na czas nieokreślony. Stawia to pracowników świadczących pracę na tej podstawie w niepewnej sytuacji. Na tym jednak poprzestać nie można. Zauważmy, że o ile zasadność rozwiązania umowy o pracę na czas określony bez wypowiedzenia można kontrolować na drodze sądowej $^{39}$, to o ile pracownik nie legitymuje się przynależnością do związku zawodowego lub nie jest objęty ochroną przez związek, nie ma możliwości zrealizowania kompetencji związku na płaszczyźnie współdziałania z pracodawcą w podejmowaniu wiążących decyzji. Stanowi to $\mathrm{w}$ perspektywie stabilności zatrudnienia na podstawie umowy o pracę na czas określony znaczną wadę, tym bardziej, co wynika z danych statystycznych, zrzeszanie się w związkach zawodowych jest coraz mniej powszechne. W 2018 r. należało do nich łącznie 1,5 mln osób. W porównaniu do $2014 \mathrm{r}$. jest to spadek o $1,1 \%{ }^{40}$.

Druga perspektywa dotyczy strony teoretycznej i programowej umowy o pracę na czas określony. Dokonanie jej jednoznacznej oceny jest trudne, aczkolwiek decydując się na obronę konkretnej tezy, określiłbym tę perspektywę, a contrario do poprzedniej jako pozytywną. Umowa o pracę na czas określony wpisuje się swoim charakterem w cechę prawa pracy, jaką jest szeroko pojęta dyferencjacja. Już w art. 25 k.p. ustawodawca dokonał podziału umowy o pracę na trzy rodzaje, w związku $\mathrm{z}$ tym, kierując się założeniem racjonalnego ustawodawcy należy przyjąć, że chciano przez to zróżnicować położenie osób, świadczących pracę na ich podstawie. Emanację tego założenia szczególnie widać w stabilności zatrudnienia. Umowy terminowe, do których zalicza się umowa o pracę na czas określony, nie stawiają $\mathrm{w}$ tak korzystnym położeniu pracowników jak umowa o pracę na czas nieokreślony. Wręcz przeciwnie. Nie można, tworząc katalog umów, dopuścić do ich prawnej tożsamości. Ustawodawca, wtórując temu założeniu, wprowadza instytucję

\footnotetext{
${ }^{37}$ J. Piątkowski, Umowa ..., s. 16.

${ }^{38}$ K. Jaśkowski, Nowa umowa o pracę na czas określony, Praca i Zabezpieczenie Społeczne 2015, nr 11, s. 3.

${ }^{39}$ Zob. art. $56 \S 1$ k.p.

40 https://stat.gov.pl/obszary-tematyczne/gospodarka-spoleczna-wolontariat/gospodarka-spoleczna-trzecisektor/partnerzy-dialogu-spolecznego-zwiazki-zawodowe-i-organizacje-pracodawcow-wynikiwstepne,16,1.html [dostęp: 22.03.2020 r.]
} 
zasadności i trybu związkowego do wytycznych determinujących zachowania pracodawcy przy wypowiedzeniu umowy o pracę tylko na czas nieokreślony. Co w sytuacji, gdyby te dwie instytucje rozszerzyć też na umowę o pracę na czas określony? Wtedy jedynie czas obowiązywania wyróżniałby ją od umowy bezterminowej ${ }^{41}$. W związku z powyższym, stabilność zatrudnienia na podstawie umowy o pracę na czas określony, oceniając z perspektywy realizacji założeń systemu prawa pracy, może być oceniana pozytywnie.

\section{Bibliografia:}

\section{Literatura}

Florek L., Prawo pracy, Warszawa 2006.

Jaśkowski K., Nowa umowa o pracę na czas określony, Praca i Zabezpieczenie Społeczne 2015, nr 11.

Łapiński K., Umowa o pracę na czas określony w polskim i unijnym prawie pracy, Warszawa 2011.

Mitrus L., Komentarz do art. $36^{1}$ Kodeksu pracy, w: Kodeks pracy. Komentarz, red. A. Sobczyk, Warszawa 2018.

Muszalski W., Komentarz do art. $25^{1}$ Kodeksu pracy, w: Kodeks pracy. Komentarz, red. W. Muszalski, Warszawa 2019.

Muszalski W., Komentarz do art. 36 Kodeksu pracy, w: Kodeks pracy. Komentarz, red. W. Muszalski, Warszawa 2019.

Piątkowski J., Udzial zwiazku zawodowego w rozwiazywaniu stosunku pracy - niedoskonałości regulacji prawnej, w: Ochrona trwatości stosunku pracy $w$ społecznej gospodarce rynkowej, red. G. Goździewicz, Warszawa 2010.

Piątkowski J., Umowa o prace na czas określony w Kodeksie pracy - nowa jakość czy powolny zmierzch tożsamości, Studia z Zakresu Prawa Pracy i Polityki Społecznej (Studies on Labour Law and Social Policy) 2016, $\mathrm{nr} 1$.

Pisarczyk Ł., Nowy model zatrudnienia pracowniczego w prawie pracy? - czesść 1, Monitor Prawa Pracy 2016, nr 4.

Stelina J., Komentarz do art. $25^{1}$ Kodeksu pracy, w: Kodeks pracy. Komentarz, red. A Sobczyk, Warszawa 2018.

Świątkowski A., Kodeks pracy. Komentarz, Warszawa 2018.

Święcicki M., Prawo pracy, Warszawa 1968.

Wąż P., Komentarz do art. 33 Kodeksu pracy, w: Kodeks pracy. Komentarz, red. K. Walczak, Warszawa 2020.

Wichrowska-Janikowska E., Umowa o prace na czas określony i na zastępstwo - jej wptyw na ksztattowanie rynku pracy - na podstawie działań Rzecznika Praw Obywatelskich, w: Konferencja

\footnotetext{
${ }^{41}$ J. Piątkowski, Umowa ..., s. 15.
} 
naukowa „Umowa o pracę na czas określony - jej rola i znaczenie w kreowaniu stosunków pracy”, red. E. Wichrowska-Janikowska, Warszawa 2004.

\section{Orzecznictwo}

Orzeczenie Sądu Najwyższego z dnia 15 grudnia 1956 r., IV CR 35/56, OSNCK 1957, nr 4, poz.118.

Uchwała Sądu Najwyższego z dnia 9 listopada 1994 r., I PZP 46/94, OSNAPiUS 1995, nr 7, poz. 87.

Wyrok Sądu Najwyższego z dnia 21 września 2011 r., II PK 36/11, Legalis nr 461864.

Wyrok Sądu Najwyższego z dnia 27 maja 2014 r., II PK 225/13, OSNAPiUS 2015, nr 11, poz. 146.

Wyrok Sądu Najwyższego z dnia 8 maja 1997 r., I PKN 123/97, OSNAPiUS 1998, nr 5, poz. 151. 